\title{
Tax Appeal Proceedings before the Federal Tax Appeal Commission in Ethiopia: Critical Reflections
}

\begin{abstract}
Under the 2016 Federal Tax Administration Proclamation (FTAP), it is by way of appeal that taxpayers reach the judiciary when they can show that the Federal Tax Appeal Commission (FTAC) has committed an error of law. As far as factual issues are concerned, the decision of the FTAC is thus final and conclusive. Ethiopia's tax dispute resolution system has made improvements although there has been discontent on the part of taxpayers. This article examines the tax appeal processes at the federal level to see whether the processes enhance fair play between taxpayers and the tax authority. Specifically, the article evaluates whether there are clear and adequate procedural rules that ensure access to justice for aggrieved taxpayers and fair treatment by the Federal Tax Appeal Commission (FTAC). I argue that although there have been certain improvements made by the FTAP (as far as administrative appeal before the FTAC is concerned), there are still some critical shortcomings that have to be reconsidered.
\end{abstract}

Aschalew Ashagre Byness *

\section{Key terms:}

Tax appeal · Tax Appeal Commission · Hearing · Burden of proof · Ethiopia

DOI http://dx.doi.org/10.4314/mlr.v14i2.2

This article is licensed under a Creative Commons Attribution-

NonCommercial-NoDerivs (CC BY-NC-ND)

Received: 30 July 2020

Accepted: 7 December 2020

\section{Suggested citation:}

Aschalew Ashagre Byness (2020), 'Tax Appeal Proceedings before the Federal

Tax Appeal Commission in Ethiopia: Critical Reflections', 14 Mizan Law

Review 2: 201-238

\footnotetext{
- Aschalew Ashagre Byness: Assistant Professor of Law, School of Law, Addis Ababa University; Consultant and Attorney at law; PhD candidate.

ORCID: https://orcid.org/0000-0002-1970-7554

E-mail: gakidan.ashagre335@gmail.com or aschalew.ashagre@aau.edu.et

I thank the anonymous reviewers for their comments. I am also grateful to the interviewees for their valuable information. This article is based on a chapter in my $\mathrm{PhD}$ research on the Ethiopian tax dispute resolution system. I thank my supervisor, Dr. Getachew Assefa (Associate Professor) for his insights and comments.
} 


\section{Introduction}

Tax is a compulsory debt levied and collected by the government of a given country irrespective of the will of an economic unit (a physical or juridical person) designated as a taxpayer by a piece of tax legislation or tax code as the case may be. ${ }^{1}$ As world history of taxation clearly demonstrates, a government has an inherent power of taxation ${ }^{2}$ whether it is dictatorial, democratic or monarchical. ${ }^{3}$ The fact that governments have the power to levy and collect tax does not mean that they are not accountable to their citizens as regards to the kind of taxation system they put in place. Therefore, tax systems have to meet certain standards by embracing critical features of a good tax system such as canons and principles of taxation. ${ }^{4}$

Equally important to the substantive content of a taxation system is creating a fair tax administration since administrative issues of taxation are as decisive as substantive issues. ${ }^{5}$ One of the most important components of a fair tax administration is the existence of a fair and efficient tax dispute

\section{Frequently used acronyms}

FAG Federal Attorney General

FAPP Federal Administrative Procedure Proclamation

FDRE Federal Democratic Republic of Ethiopia

FHC Federal High Court

FTAC Federal Tax Appeal Commission

FTAP Federal Tax Administration Proclamation

FTAR Federal Tax Administration Regulation

HoPR House of People's Representatives

PM Prime Minister

${ }^{1}$ See Victor Thuronyi (2003), Comparative Tax Law, Kluwer Law International, New York, p.45.

${ }^{2}$ Odd-Helge Fjeldstad (2001), 'Taxation, Coercion and Donors: Local Government Tax Enforcement in Tanzania,' Journal of Modern African Studies, Vol. 39, No. 2, p. 293.

${ }^{3}$ See Hanneke Du Freez (2015), A Construction of Fundamental Principles of Taxation, Ph.D. Thesis, Unpublished, Faculty of Economics and Management Sciences, at the University of Pretoria,pp.46-61.

${ }^{4}$ Clinton Alley and Duncan Bentley (2005), A Remodeling of Adam Smith's Tax Design Principles, Australian Tax Forum,p.586; see also Beverly I. Moran, 'Adam Smith and the Search for an Ideal Tax System,' available at taxprof.typepad.com/taxprof_blog/files/Moran.pdf, accessed on July 15, 2020

${ }^{5}$ Richard M. Bird, 'Improving Tax Administration in Developing Countries,' Journal of Tax Administration Vol.1, No.1, pp.23-38; see also Richard M. Bird (2004), 'Administrative Dimensions of Tax Reform,' Asia-Pacific Tax Bulletin, pp.134-150. 
Tax Appeal Proceedings before the Federal Tax Appeal Commission in Ethiopia... 203

resolution system. ${ }^{6}$ That is why many jurisdictions have established both internal (administrative) disputes resolving organ or department or section within the tax authority and external dispute resolution bodies such as quasijudicial tax tribunals (commissions), a special tax court or ordinary courts as the case may be. Alternative Dispute Resolution (ADR) mechanisms are also employed in various jurisdictions. ${ }^{7}$

In Ethiopia, the foundation for modern taxation was laid down starting from the early $1940 \mathrm{~s}^{8}$ and resolution of tax disputes by a tax appeal commission has remained the hallmark of the Ethiopian tax dispute resolution system. ${ }^{9}$ The Federal Tax Appeal Proclamation (FTAP) has also retained the tax appeal commission as a tax appellate organ. ${ }^{10}$ Under the FTAP, taxpayers aggrieved by the decision of the tax authority are entitled to take their appeals against tax decisions to the FTAC by meeting the preconditions set forth by the Proclamation. When a tax dispute involves only a question of fact, the decision rendered by the FTAC remains nonappealable to the regular appellate courts, which demonstrates that regular appellate courts in Ethiopia are absolutely debarred from entertaining tax appeals that do not contain question of law. ${ }^{11}$ The adjudicative power of the Federal Tax Appeal Commission (FTAC) is thus very much influential and far reaching in Ethiopia.

This article examines legal (procedural) and practical issues relating to the resolution of tax disputes by the FTAC. The main research method is doctrinal, with due focus on the relevant provisions of the FDRE Constitution, the FTAP, Federal Tax Administration Regulation (FTAR), directives issued by the Prime Minister and the FTAC, provisions of the Civil Procedure Code and other legal instruments. In order to shed some light on how the law is implemented on the ground (the law in action), the doctrinal method is supplemented by empirical qualitative research as the

${ }^{6}$ Binh Tran-Nam and Michael Walpole (2012), 'Independent Tax Dispute Resolution and Social Justice in Australia,' University of New South Wales Law Journal, Vol. 35, No.2, pp.470-474.

${ }^{7}$ See generally Simon Whitehead (ed.), Tax Disputes and Litigation Review, Law and Business Research, 2018.

8 Taddese Lencho (2012), 'Towards Legislative History of Modern Taxes in Ethiopia (1941-2008),' Journal of Ethiopian Law, Vol. 25, No.2, pp. 104-158.

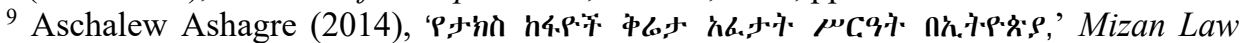
Review, Vol.8, No.1, pp. 202-208.

${ }^{10}$ Federal Tax Administration Proclamation, Proc. No.983/2106, Fed. Neg., Extraordinary Issue, Year 22, No. 103, Art. 86.(Hereinafter cited as FTAP)

${ }^{11}$ Id, Arts. 56-58. 
latter is instrumental to capture and categorize social phenomena and their meanings. ${ }^{12}$ To this end, the author has conducted in-depth interviews with fifteen (15) purposely selected individuals (consisting of members of the FTAC, tax practitioners, lawyers and taxpayers), has analyzed relevant documents and has made use of his personal observations as consultant and attorney at law.

The first section provides an overview on the resolution of tax disputes by tax appeal tribunals, and Section 2 discusses the establishment, constitutional status and the appellate power of the FTAC. The third section examines issues pertaining to membership to the FTAC (focusing on selection, appointment, composition and termination). The fourth and fifth sections address critical issues arising in connection with the appellate proceedings: preconditions to lodge an appeal, memorandum (notice) of appeal, appearance of the parties at the time of hearing and the effects of non-appearance, hearing procedures and burden of proof. The sixth section deals with procedural issues arising in relation to decision-making procedures and the enforcement of FTAC decisions. Finally, brief concluding remarks have been made.

\section{Resolution of Tax Disputes by a Tax Appeal Tribunal: An Overview}

Tax disputes are common in all jurisdictions, ${ }^{13}$ and they occur where there is discordance between the tax authority and the taxpayer regarding the taxpayer's liabilities or rights and associated issues. ${ }^{14}$ That is why tax dispute resolution mechanisms exist in all legal regimes in spite of their variation in content, the way they are organized, staffed and operation. ${ }^{15}$ Despite such variation, tax disputes are resolved by internal review organs, tax tribunal (board or commission), special tax courts, regular courts (mostly by way of review) and different kinds of ADR methods. ${ }^{16}$

${ }^{12}$ Lisa Webley (2010), Qualitative Approaches to Empirical Legal Research, in Peter Cane and Herbert Kritzer (eds.), The Oxford Handbook of Empirical Legal Research, p.2.

${ }^{13}$ Tran-Nam and Walpole cited above at note 6, p. 473.

${ }^{14}$ Melinda Jone (2016), Tax Dispute Systems Design: International Comparisons and the Development of Guidance from a New Zealand Perspective, Ph.D. thesis, unpublished, Department of Accounting and Information Systems in the University of Canterbury, p.19.

${ }^{15}$ See Simon Whitehead, cited above at note 7.

${ }^{16}$ Ibid. 
Tax Appeal Proceedings before the Federal Tax Appeal Commission in Ethiopia... 205

Where tax appeal tribunals (boards, commissions, etc.) have appellate jurisdiction and their decisions become final and conclusive as far as factual issues are concerned, taxpayers do not have, as a matter of rule, direct access to ordinary courts or administrative courts without first exhausting the remedies available to them before the tax tribunal. This approach is common in many jurisdictions. Tax appeal tribunals are preferred to regular or administrative appellate courts for various reasons. Although it is believed that appeal tribunals substitute courts as far as the resolution of disputes arising between an administrative agency (the tax authority in our case) and private persons (taxpayers) is concerned, they are considered to be more advantageous than courts owing to speed, relatively lesser cost, informality and expertise. ${ }^{17}$ In addition, it was argued that the establishment of administrative tribunals for tax cases is justified to entertain disputes, such as tax disputes, arising between an administrative agency and individuals. ${ }^{18}$

According to Bradley and Ewing, the creation of administrative tribunals is indispensable because the ordinary courts are not suitable for the settlement of every dispute arising from the works and functions of modern government in general and tax administration in particular. One reason for this, according to these authors, is the need to make use of specialized knowledge which is instrumental to the resolution of disputes fairly and economically. They maintained that areas such as taxation, social security or immigration (which involve complex systems of regulation) call for numerous decisions to be made by individuals trained in those fields. ${ }^{19}$ It is also argued that:

Practical factors that have favored the setting up of tribunals include: the desire for a procedure which avoids the formality of the courts; the need, in implementing a new social policy, for the speedy, cheap and decentralized determination of many individuals' cases, which may include not only lawyers but also other professionals with relevant experience. ${ }^{20}$

The resolution of tax disputes by tribunals is also believed to encourage applicants because they get the service of administrative justice at a relatively low cost as compared to the cost incurred in ordinary court

\footnotetext{
${ }^{17}$ See Diane Longley and Rhoda James (1999), Administrative Justice: Central Issues in UK and European Administrative Law, Cavendish Publishing Limited, p. 95.

${ }^{18}$ Ibid.

${ }^{19}$ A W Bradley and K D Ewing (2007), Constitutional and Administrative Law, Pearson Longman, p. 695.

${ }^{20} \mathrm{Id}$, p. 696.
} 
litigation. ${ }^{21}$ Tribunals are also appreciated because of flexibility since they usually avoid strict legal approach which is the typical feature of ordinary courts. The flexible approach of tribunals manifests itself in relation to conducting proceedings, rules of evidence and interpretation of statutes. ${ }^{22}$ Furthermore, administrative tribunals are best known for using the inquisitorial mode as opposed to the adversarial mode of litigation which is not suitable to cases submitted to the tribunals. When the approach is inquisitional, it is highly likely that justice is done as is the case even in ordinary litigation in the continental legal system. ${ }^{23}$

\section{The Federal Tax Appeal Commission: Establishment, Constitutional Status and Scope of Appellate Power}

\subsection{Establishment and constitutional status}

Modern tax history of Ethiopia has attached significant weight to the disposition of tax cases by a special tribunal. ${ }^{24}$ The FTAC is an independent tribunal which is empowered to accept and entertain tax appeals lodged against appealable decisions made by the Tax Authority on taxes reserved to the Federal Government. ${ }^{25}$ The FTAC was accountable to the Prime Minister ${ }^{26}$ for a short period, and it is currently accountable to the Federal Attorney General (FAG) since October 2018 based on a proclamation issued to define the powers and duties of the executive organs of the FDRE Government. $^{27}$

Owing to the absence of concrete and comprehensive tax policy that deals with tax administration in general and tax dispute resolution in

${ }^{21}$ Peter Leyland and Gordon Anthony (2013), Textbook on Administrative Law, $7^{\text {th }}$ ed, Oxford University Press, p.157.

${ }^{22} \mathrm{Id}, \mathrm{p} .158$.

${ }^{23} \mathrm{Id}, \mathrm{p} .159$.

${ }^{24}$ See AschalewAshagre, cited above at note 9, pp. 202-210.

${ }^{25}$ FTAP, cited above at note 10, Art. 86(1).

26 During public consultations, there were individuals from among the taxpaying community who argued that the FTAC should not be accountable to the Ministry of Justice (now Federal Attorney General) alleging that the independence and impartiality of the Commission would be compromised. See also Aschalew Ashagre (2016), Review of the Ethiopian Income Tax Appeal System: Issues of Concern and Recommendations, unpublished, research conducted by the sponsorship of the International Financial Corporation (IFC), hereinafter cited as Review of the Ethiopian Income Tax Appeal System.

${ }^{27}$ Definition of Powers and Duties of the Executive Organs of the Federal Democratic Republic of Ethiopia, Proc.No.1097/2019, Fed. Neg. Gaz. Year 25, No.8, Art.33(8). 
Tax Appeal Proceedings before the Federal Tax Appeal Commission in Ethiopia... 207

particular, ${ }^{28}$ it has remained quite easy for the Government of Ethiopia to change the accountability of the FTAC (from the Prime Minister to the FAG) without any acceptable and convincing justifications. ${ }^{29}$ In this regard, two interviewees opined that the law-maker made the FTAC accountable to the FAG without being mindful of the fact that the FTAC was made accountable to the PM under the FTAP as there is an acute problem of institutional memory at the HoPR. ${ }^{30}$

Nonetheless, it may be argued that nothing is wrong with making the FTAC accountable to the FAG as long as there are legal safeguards and political commitment to ensure the independence and impartiality of the FTAC. Contrary to this line of argument, several interviewees are of the view that the FTAC has to be accountable to the PM since such arrangement enhances the independence and accountability of the FTAC. ${ }^{31}$ There are practices in other jurisdictions as well where a tax appeal tribunal is accountable to the Attorney General. For instance, the Income Tax Appellate Tribunal in India and Taxation Review Authority in New Zealand are accountable to the Ministry of Justice of the respective countries while the Australian Administrative Appeals Tribunal (AAT) "falls within the portfolio of the Attorney General."32

28 Taddese Lencho (2014), 'Articulating Ethiopia's Current Tax Policy: Sources and Fundamental Objectives,' in Taddese Lencho and Kyle Logue (eds.), Ethiopian Tax System: Some Contemporary Issues and Problems, Ethiopian Business Law Series, Vol.VI, pp.1-26.

${ }^{29}$ In fact, there are individuals who argue that because the Prime Minister has different critical responsibilities, it is not appropriate to make the FTAC accountable to the Prime Minister. According to these individuals, it would be difficult for the Prime Minister to supervise and control the FTAC because of his busy schedule and high national responsibilities.

30 Interview with Serkalem Eniyew, member of the FTAC, September 25, 2020; interview with Mulugeta Ayalew, president of the FTAC, September 28, 2020.

${ }^{31}$ Interview with Ali Mohammed, Consultant and attorney at law, September 20, 2020; interview with Teferra Lema, Chief Executive officer of Steely RMI PLC, Addis Ababa, September 22, 2020; interview with Tolu Fite, Manager of North West Branch, Ministry of Revenues, October 28,2020; interview with Wondiye Girma, consultant and attorney at law, September 18, 2020; interview with Husamudin Seifu, General Manager of My Wish Enterprise PLC, September 26, 2020 ; Interview with Girma Debele, tax accountant and consultant, Manager of Peak Authorized Accounting Firm, September 28, 2020.

${ }^{32}$ Satoru Araki and Iris Claus (April 2014), 'A Comparative Analysis of Tax Administration in Asia and the pacific,' available at 
The other important issue arising in relation to tribunals in general and the FTAC in particular is the issue of constitutionality. Constitutional questions in connection with administrative tribunals usually arise in other jurisdictions although various administrative tribunals, including tax appeal tribunals, have proliferated in all continents. For instance, the Indian Constitution that entered into force in 1950 did not embody a provision regarding administrative tribunals. Therefore, the constitutionality of tribunals became controversial ${ }^{33}$ until this gap was resolved under the amended Indian Constitution. ${ }^{34}$ Following the amendment of the Constitution, the Indian parliament enacted the Administrative Tribunal Act in 1985 through which the central Administrative Tribunal was established with five benches. Therefore, administrative tribunals in India have firm constitutional basis and hence their status cannot be controversial so long as they exercise their adjudicative powers in accordance with the Constitution. ${ }^{35}$ The establishment and powers of tribunals vis-à-vis the regular courts provoked constitutional disputes in jurisdictions such as the USA, Jamaica, Australia, ${ }^{36} \mathrm{Canada}^{37}$ and the like.

In Ethiopia, although appeal to a tax appeal tribunal has been embodied in the Ethiopian tax dispute resolution system since the early 1940s, the FDRE Constitution does not expressly contain a clear provision regarding the status of tax appeal tribunals. ${ }^{38}$ The issue of tribunals was raised during the discussion of the draft constitutional provisions by the members of the Constitutional Assembly. The issue of tribunals was discussed in relation to Art. 37(1) of the draft which stated "that everyone has the right to bring a justifiable matter to and to obtain a decision or judgment by a court of law or any other competent body with judicial power." It was the phrase "any other competent body with judicial power" that was a source of heated debate as participants seriously questioned as to what message was conveyed by this phrase.

https://www.adb.org/publications/comparative-analysis-tax-administration-asia-andpacific, accessed on April 22, 2020, p. 63.

${ }^{33}$ Arvind P. Datar (2006), The Tribunalisation of Justice in India, 2006 Acta Juridica, p.288.

${ }^{34}$ Ibid, See also Indian Constitution, Arts. 323 A and 323B.

${ }^{35}$ K.C. Joshi (1999), 'Constitutional Status of Tribunals,' Journal of the Indian Law Institute, Vol. 41, No. 1, pp. 116-117.

${ }^{36}$ Ibid

${ }^{37}$ See David J. Mullan (1982), 'The Uncertain Constitutional Position of Canada's Administrative Appeal Tribunals,' Ottawa Law Review, Vol.14, pp. 239-269.

38 It has to be borne in mind that the FDRE Constitution does not have express provisions dealing with the status of other administrative tribunals. 
Tax Appeal Proceedings before the Federal Tax Appeal Commission in Ethiopia... 209

The panelists who were providing answers to the questions underscored that courts are not the only state organs that entertain cases; rather, administrative tribunals, such as the tax tribunals, could accept cases and could give binding decisions. ${ }^{39}$ The reading of Art. 37(1) of the FDRE Constitution together with its drafting history indicate that administrative tribunals in general and tax appeal tribunals in particular were duly recognized by the makers of the Constitution although the Constitution does not unequivocally declare the status of administrative tribunals such as the FTAC. Reference to legislative intent thus shows that the words "any other competent body with judicial power" in Article Art. 37(1) of the FDRE Constitution can be interpreted as administrative tribunals including FTAC.

The status of administrative tribunals was also raised during the discussion on Art. 78(4) of the FDRE Constitution which states that "special or ad hoc courts which take judicial powers away from the regular courts or institutions legally empowered to exercise judicial functions and which do not follow legally prescribed procedures shall not be established." As we can see from the minutes of the Constitutional Assembly, the discussion centered on the non-establishment of special or ad hoc criminal courts as those that were operating during the early years of the Dergue Regime for the purpose of punishing political dissent and armed opposition groups. ${ }^{40}$

The Minutes show that Art. 78(4) was not meant to ban the establishment of administrative tribunals including tax appeal tribunals. ${ }^{41}$ Therefore, it can cogently be concluded that the FDRE Constitution gave recognition to administrative tribunals such as the FTAC so long as the inherent powers of the regular courts are not affected by the existence of particular administrative tribunals. Yet, Yared argues that the establishment of various administrative tribunals in general and tax appeal tribunals in particular that are not controlled by the judiciary is an act of court stripping. ${ }^{42}$ In this regard, Assefa Fisseha also stated that: ${ }^{43}$

39 See Minutes of the Constitutional Assembly of Ethiopia (Amharic), unpublished, Vol.3, Minutes No19, PP.13-15, available with the author in soft copy.

${ }^{40}$ See Minutes of the Constitutional Assembly of Ethiopia (Amharic), unpublished, Vol.5, Minutes No.27, pp.9-18 and No. 28 pp.3-11, available with the author in soft copy.

${ }^{41}$ Ibid.

42 See Yared Legese, 'Court Stripping: A Threat to Judicial Independence, 'in Gedion Timotheows and Helen Fikre (eds.), The FDRE Constitution: Some Perspectives on the Institutional Dimension, Ethiopian Constitutional Law Series, Vol.6.,pp.91-161.

${ }^{43}$ Assefa Fiseha (2006), Federalism and the Accommodation of Diversity in Ethiopia, Wolf Legal Publishers, the Netherlands, pp.412-413. 
The judicial system, as compared to other federations, stands constrained in its jurisdiction. Even within the limited powers conferred by the Constitution, several internal as well as external factors seem to be at play to maintain the judiciary's law profile. Firstly, judicial powers are being taken away from regular judiciary to special other tribunals whose constitutional status is controversial. When there is legislative leeway for intervention, governments often decide to 'strip' courts of their jurisdiction to adjudicate matters in which the government of the day has vital interests or they may transfer jurisdiction over such matters from the regular courts to tribunals whose decision makers often lack the security of tenure or expertise enjoyed by the judiciary.

While Assefa's argument is basically correct in light of the establishment of certain administrative tribunals which have eroded the powers of regular courts, it is hardly possible to fully subscribe to his argument as far as the status of the FTAC is concerned as the Commission has remained to be the hallmark of the Ethiopian tax system since the early 1940s. Nevertheless, the Constitution should have expressly recognized administrative tribunals since administration of justice cannot solely be given to courts.

\subsection{Scope of FTAC's appellate power}

In Ethiopia, the appellate power of the FTAC is regulated by FTAP which provides that a taxpayer dissatisfied with an appealable decision or any other decision made by the Tax Authority can file a notice of appeal with the FTAC $^{44}$ seeking variation or reversal of the Tax Authority's decision. Art. 2(2) of the FTAP states that "an appealable decision is an objection decision and any other decision of the authority made under a tax law to the exclusion of a tax decision and a decision made by the authority in the course of making a tax decision." An objection decision, is a final and binding decision made by the Tax Authority, on the basis of a recommendation made by the Review Department, on any tax issues indicated under Art. 2(34) of the FTAP. ${ }^{45}$

${ }^{44}$ FTAP, cited above at note 10, Art. 56(1) cum Art. 88.

${ }^{45} \mathrm{Id}$, Art. 2(34) of the FTAP has enumerated what tax decisions are. According to this sub-article, a tax decision is a tax assessment (other than a self-assessment), a decision on application under Art. 29, a determination made under Art. 40(2), a determination of a secondary liability or the amount of tax recovery costs payable, a determination of late payment interest payable, a decision to refuse an application for a refund under Art. 49 or Art.50, a determination of the amount of an excess credit under Art. 49, the amount of a refund under Art. 50or the amount of refund required to be repaid under Art. 50 and a determination of the amount of unpaid withholding tax under Art. 92(3) of the Federal Income Tax Proclamation (FITP). 
Tax Appeal Proceedings before the Federal Tax Appeal Commission in Ethiopia... 211

The phrase any other decision of the tax authority that may be reviewed by the FTAC can be a source of confusion and uncertainty regarding the scope of the appellate power of the FTAC although the principle of certainty is one of the most important principles of a modern tax administration in general and tax dispute resolution in particular. ${ }^{46}$ The practice is also of no help to grasp the essence of this issue since such issue has not arisen before the FTAC as indicated by the responses of members of the FTAC. ${ }^{47}$

It may be validly argued that the FTAC may have the power to accept and entertain any other non-tax assessment appeal lodged against the decision of the tax authority since the Proclamation has provided that a taxpayer has the right to lodge an appeal against any other decision of the Tax Authority affecting a taxpayer directly or indirectly. However, when we examine the provisions of the FTAP dealing with the powers of the FTAC as a whole, it is untenable to conclude that the FTAC is empowered to accept any complaint lodged against any decision made by of Tax Authority using its discretionary power.

For instance, the Tax Authority has the discretion to revoke Tax Identification Number (TIN) ${ }^{48}$ order temporary closure of a business, ${ }^{49}$ order registration for tax in general $^{50}$ and registration for VAT in particular. ${ }^{51}$ Exercising such powers is an inherent discretion of the Tax Authority which compels us to question whether or not the FTAC has a legitimate power to review such decisions if a taxpayer is aggrieved by such decisions. At any rate, the scope of review power of the FTAC definitely exceeds the scope of Review Power of the Review Department whose recommendation that is approved by the Tax Authority can become an appealable decision.

In view of Ethiopia's current administrative law after the coming into force of the Federal Administrative Procedure Proclamation (FAPP) in March 2020, ${ }^{52}$ it is worthwhile to evaluate the scope of appellate power of

46 See E. W. Thomas (1999), 'Fairness and Certainty in Adjudication: Formalism v Substantialism,' Otago Law Review, Vol.9, No.3, pp. 459-488.

${ }^{47}$ Interview with Serkalem Enyew and Mulugeta Ayalew, cited above at note 30.

${ }^{48}$ FTAP, cited above at note 10, Art. 15 .

${ }^{49} \mathrm{Id}$, Art. 45 .

${ }^{50}$ Id, Art.9.

${ }^{51}$ Value Added Tax Proclamation, Proc. No. 285/2002, Fed. Neg Gaz., Year 8,No.33, Art. 16.

52 Federal Administrative Procedures Proclamation, Proc. No.1183/2020, Fed. Neg. Gaz., Year 26, No.33. 
the FTAC in light of the relevant provisions of the FAPP. The FAPP provides that any individual, who is aggrieved by an administrative decision, has the right to take his grievance to an internal review organ of an administrative agency, the Review Department in tax case. ${ }^{53}$ However, if he is not satisfied with the decision of the internal review organ, he has the right to appeal to the Federal High Court (FHC) for judicial review. ${ }^{54}$ Therefore, a question arises whether taxpayers are required at all to lodge appeals to the FTAC against decisions made by the tax authority on matters of taxation which are not included under Art. 2(34) of the FTAP.

Two opposing arguments may be raised in response to this issue. One may argue that because the FAPP is applicable to any decision of a federal administrative agency and the Tax Authority is also an administrative agency, a taxpayer aggrieved by the decision of Tax Authority which is not covered by Art. 2(34) of the FTAP is not required to go to the FTAC. Instead, he has the right to lodge an appeal to the FHC for judicial review so long as the internal review organ of the Tax Authority has examined the complaint and approved the original administrative decision of the Tax Authority.

On the other hand, it may be argued that passing through the FTAC is mandatory even in non-tax assessment cases since the FTAP is special law dealing, inter alia, with the resolution of tax disputes while the FAPP is a general law dealing with all administrative procedural issues in general. Such controversy could have been easily avoided (i) if the FTAP had defined the cases that can be appealed to the FTAC other than objection decisions, and (ii) if the FAPP had clearly indicated its scope of application to matters that are dealt with by special administrative procedural rules in Ethiopia's tax laws.

It has to be noted that the FAPP has failed to recognize the powers granted to administrative appeal tribunals, such as the FTAC, as it has boldly provided that once an internal administrative remedy is exhausted, resort to the FHC is possible for judicial review. ${ }^{55}$ Because of the unclear positions of these two proclamations, there could be a problem of forum shopping which results in different decisions by the FTAC and the FHC on the same legal issues. The best remedy is, therefore, to clearly define the scope of appellate

\footnotetext{
${ }^{53}$ Id, Arts.42-43.

${ }^{54}$ Id, Art. 52.

${ }^{55}$ Ibid.
} 
Tax Appeal Proceedings before the Federal Tax Appeal Commission in Ethiopia... 213

power of the FTAC as far as disputes that do not involve tax assessment are concerned. ${ }^{56}$

\section{Membership to the Commission}

The independence, impartiality and effectiveness of a tribunal largely depends on the composition of members and the manner in which members are appointed and removed. For instance, in Tanzania members of the Tax Revenue Appeals Tribunal are appointed by the Minister of Finance ${ }^{57}$ while the President of the tribunal is appointed by the President of the Republic after consultation with the Chief Justice. ${ }^{58}$ In Zambia, both the chairperson and the ordinary members of the Tax Appeals Tribunal are appointed by the Minister of Finance as provided by the 2015 Tax Appeals Tribunals ACT. ${ }^{59}$ Likewise, members of the Tax Appeal Tribunal are appointed by the Ministry of Finance in Nigeria. ${ }^{60}$

In Ethiopia, the FTAP states that both the President of the FTAC and members are appointed by the Prime Minister (PM). ${ }^{61}$ Regarding the criteria to be used for eligibility to membership, the FTAP states that an individual may be appointed as a member of the Commission if he is a lawyer with a significant experience in tax or commercial matters, a member of the Institute of Certified Public Accountants with significant experience in tax matters, and if the individual has previously been engaged as a tax officer with significant technical and administrative experience in tax matters or has special knowledge, experience, or skills relevant to the function of the Commission. ${ }^{62}$ The word 'significant' is an extremely subjective standard for the selection and appointment of members of the Commission, and proper attention should have been given to the inclusion of clear and specific criteria of selection and appointment of members of the Commission

\footnotetext{
${ }^{56}$ Interview with Tekka Mehari, Consultant and Attorney at Law, September 20, 2020.

57 See the United Republic of Tanzania Revenue Appeals Act, 2006, available at http://repository.businessinsightz.org/handle/20.500.12018/285, accessed on March 20, 2020, Art. 8(2.c).

${ }^{58}$ Id, Art. 8(2.c).

${ }^{59}$ The Tax Appeals Tribunal Act of Zambia, 2015. Available at https://zambialii.org/node/1075 (Accessed on March 20,2020)

60 Agbonika Josephine Aladi Achor (2014), 'Tax Dispute Resolution in Nigeria: A Storm in a Tea Cup,' Journal of Law, Policy and Globalization, Vol. 29, pp. 147-156.

${ }^{61}$ FTAP, cited above at note 10, Art. 86(2) cum Art. 87(1).

${ }^{62}$ Id, Art. 87(2).
} 
commensurate with the complicated and sensitive tax appeals arising from the federal tax laws.

In addition to enumerating the general criteria of appointment for membership to the Commission, the FTAP enumerates persons who cannot be appointed as member of the Commission. As stated under Art. 87(3) of the FTAP, first, the PM shall not appoint "a currently serving tax officer or an individual who has ceased to be a tax officer for a period of less than two years" which is an important prohibition because it helps to enhance the independence and impartiality of the Commission. ${ }^{63}$ In fact, this is a very useful departure made by the FTAP as the Ethiopian Revenues and Customs Authority (ERCA) was represented by two members making it a judge on its own case which was serious source of discontent on the part of taxpayers. ${ }^{64}$

Secondly, an individual who has been liable for a penalty or convicted of an offence under a tax law relating to tax avoidance or evasion cannot be appointed as a member. ${ }^{65}$ Thirdly, the PM shall not appoint an individual as a member of the Commission who has been convicted of a crime of corruption $^{66}$ and finally an individual who is an un-discharged bankrupt cannot be appointed as a member of the Commission. ${ }^{67}$

The composition of the members of a tribunal is an important concern. ${ }^{68}$ However, the FTAP has failed to provide for an indicative professional mix of members relating to the number of lawyers, tax accountants or previous tax officers and individuals with special knowledge about the Commission to be appointed by the Prime Minister. This shows that determining the mix of the members of the Commission is totally left to the PM.

A closer examination of Art. 87(2) of the FTAP reveals that the law does not expressly provide for representation of the tax-paying community in the FTAC. In this regard, the FTAP has clearly regressed as compared to tax laws issued during the $1940 \mathrm{~s},{ }^{69}$ the $1970 \mathrm{~s}^{70}$ and Proc. No. $608 / 2008^{71}$ which

${ }^{63}$ FTAP, cited above at note 10 , Art. 83(3)(a).

${ }^{64}$ Aschalew, cited above at note 9, p.217.

${ }^{65}$ FTAP, cited above at note 10, Art. 83(3)(b).

${ }^{66}$ Id, Art. 83(3)(c).

${ }^{67}$ Id, Art. 83(3)(d).

${ }^{68}$ Peter Cane (2009), Administrative Tribunals and Adjudication, Oxford and Portland, Oregon, pp. 103-105.

${ }^{69}$ See The Personal and Business Tax Proclamation, Proc. No 107/1949, cited above at note 24, Art. 4(vii). As provided under this sub-article, of the seven members of the Tax Appeal Commission, three members would be appointed by the Emperor from among the merchants and manufacturers doing business in Ethiopia. 
Tax Appeal Proceedings before the Federal Tax Appeal Commission in Ethiopia... 215

provided for the representation of the taxpaying community in the tax appeal commission.

In practice, one panel of the FTAC is filled with five individuals who are all legal professionals drawn from various government institutions, and this shows that there is a clear discrepancy between the law and the practice. ${ }^{72}$ According to members of the FTAC, a member is not appointed from the business community. In fact, they argued that it is not worthwhile to include such person as he may be partial to the business community. ${ }^{73}$ However, other professionals interviewed by this author argue that the business community should be represented since doing so makes them feel accommodated in the appellate process. They stated that such representation helps the FTAC to have enhanced awareness of balanced perspectives on tax issues and policies including views of a representative from the business community. $^{74}$

For instance, in Zambia, the number of members to the Tax Appeals Tribunal is seven consisting of three legal practitioners with experience of ten years or more who are recommended by the Judicial Service Commission and who have sufficient knowledge and experience in tax matters, two qualified accountants certified as such by the Zambia Institute of Chartered Accountants and two persons from the business community. ${ }^{75}$ The Tanzanian Tax Revenue Appeals Act provides that the Tax Revenue Appeals Tribunals consists of a chairman, two vice-chairmen, and four other ordinary

70 See Rural Land Use Fee and Agricultural Activities Income Tax Proclamation (Proc. No. 77/1976, Neg. Gaz., Year 30, No. 19), Art. 29(2). As per this sub-article, taxpayers would be represented in the Woreda Tax Appeal Committee by the chairman of the Worda Peasant Association. Likewise, Art. 10(1) of the Urban Land Rent and Urban House Taxes Proclamation (Proc. No.80/1976, Neg. Gaz., Year 30, No. 25) clearly provides that the Tax Appeal Committee would include a representative from the cooperative societies of urban dwellers which shows that the taxpaying community was represented by such person.

71 See Income Tax (Amendment) Proclamation, Proc. No.608/2008, Fed. Neg. Gaz. Year 15, No. 15 (now repealed). Art. 2 (12) states that the Tax Appeal Commission would include representatives from the business community.

${ }^{72}$ Interview with Serkalem Eniyew and Mulugeta Ayalew, cited above at note 30.

${ }^{73}$ Ibid.

${ }^{74}$ Interview with Yoseph Aemero, consultant and attorney at law, September 21, 2020; interview with Yohannes Woldegebriel, Director of the Arbitration Institute, Addis Ababa Chamber of Commerce and Sectorial Association, September 23, 2020.

75 The Tax Appeals Tribunal Act of Zambia, cited above at note 59, Art.4. 
members. $^{76}$ In Nigeria, each TAT (Tax Appeal Tribunal) division is composed of five tax appeal commissioners headed by a chairman who must be a lawyer with not less than fifteen years of cognate experience in tax matters while the other commissioners must be knowledgeable about tax laws, regulations, norms, practices and operations of taxation. ${ }^{77}$

In Ethiopia, the numbers and composition of members is to be freely determined by the PM since the FTAP has provided that the PM is empowered to "appoint such number of members to the Commission as he considers necessary having regard to the needs of the Commission." ${ }^{, 78}$ This means that the PM is vested with a wide discretionary power in determining the number of members of the Commission.

With regard to tenure, members of tax administrative tribunals are appointed for three years in Tanzania although they are eligible for reappointment ${ }^{79}$ and in Zambia members are appointed for four years. ${ }^{80} \mathrm{In}$ USA, administrative law judges are appointed for an indefinite period of time and can be removed only for good cause after a hearing has been conducted before the Merits System Board. Members of tribunals are appointed for a fixed period of time in England and they may be removed from office by the Lord Chancellor on account of inability or misbehavior. ${ }^{81}$

In Ethiopia, members of the FTAC are appointed for three years, and are eligible for reappointment provided that they meet the criteria of appointment at the time of reappointment. ${ }^{82}$ The appointment of a member can be terminated if the member becomes employed or engaged as a tax officer, is liable to penalty or convicted of an offence under a tax law relating to tax avoidance or evasion, is convicted of a crime of corruption under the Corruption Crimes Proclamation or any other law, or if the individual becomes an un-discharged bankrupt. Other grounds of termination include resignation by notice in writing to the PM and removal by the PM for inability to perform the duties of office or for proven misconduct. $^{83}$

\footnotetext{
${ }^{76}$ The United Republic of Tanzania Revenue Appeals Act, cited above at note 55, Art. $8(1)$.

${ }^{77}$ Achor, cited above, note 60, p.148.

${ }^{78}$ FTAP, cited above at note 10 , Art. 87(1).

79 The United Republic of Tanzania Revenue Appeals Act, cited above at note 56, Art. $9(2)$.

${ }^{80}$ The Tax Appeals Tribunal Act of Zambia, cited above at note 59, Art. 4(3).

${ }^{81}$ Cane, cited above at note 68, p.101.

${ }^{82}$ FTAP, cited above, note 10, Art. 87(4).

${ }^{83}$ Id, Art. 87(5).
} 
Tax Appeal Proceedings before the Federal Tax Appeal Commission in Ethiopia... 217

\section{Filing Appeal before the FTAC}

\subsection{The time limit requirement}

A taxpayer, aggrieved by the decision of the Tax Authority, has the right to lodge an appeal to the FTAC by meeting the pre-conditions stipulated by the FTAP. ${ }^{84}$ The first precondition is that an aggrieved taxpayer should lodge an appeal to the FTAC within 30 days of service of notice of the appealable decision. ${ }^{85}$ This time limit has remained unchanged since the 1940 s. $^{86}$ However, the FTAP provides that the time limit of 30 days may be extended by the Commission where the taxpayer shows to the Commission good cause for not filing the appeal within 30 days. ${ }^{87}$ To this end, the FTAP has made it clear that the Commission may issue a directive. ${ }^{88}$ This is an important departure which aims at enhancing access to justice for taxpayers.

Accordingly, the Commission issued a directive which enables the taxpayer to request for extension of time before the lapse of the (30 days) timeline stated in the Proclamation. ${ }^{89}$ When the Commission believes that the taxpayer was not able to file the appeal within the 30 days' time owing to force majeure or any other convincing reason, it may grant an extension of time not exceeding 15 days. ${ }^{90}$ However, the directive does not specify the reasons that may justify the extension of the time for appeal thereby providing discretionary power to the judges of the Commission. For example, there are circumstances where the FTAC grants extension if an appellant is not able to file the appeal because of financial constraint to pay the $50 \%$ of the disputed amount of tax. ${ }^{91}$

Moreover, the directive has given additional chance to taxpayers to lodge appeals after the lapse of the 30 days' time limit, as is the case in civil appeals regulated by the Civil Procedure Code of Ethiopia, ${ }^{92}$ despite the

\footnotetext{
${ }^{84}$ Id, Art. 56(1).

${ }^{85}$ Id, Art. 88(1).

${ }^{86}$ See the proclamations enumerated under foot number 24 above.

${ }^{87}$ FTAP, cited above at note 10 , Art. 88(3).

${ }^{88}$ Id, Art. 88(4).

${ }^{89}$ Directive Issued to Define the Procedures of Extension of Time of Appeal or Appeal out of Time (in Amharic) by the Federal Tax Appeal Commission, Directive No.2/ 2011 E.C, available with the author in soft copy, Art.4. ( Hereinafter cited as FTAC Directive )

${ }^{90} \mathrm{Id}$, Art.5.

${ }^{91}$ Interview with Serkalem Eniyew, cited above at note 30.

${ }^{92}$ See Civil Procedure Code of Ethiopia, Decree No. 52/1965, Extraordinary Issue, Neg. Gaz. Year 25, No. 3, Art. 328.
} 
silence of the FTAP in this regard. The Directive states that the taxpayer shall file an application which requests the Commission for permission to lodge an appeal out of time in which case the Commission notifies the Tax Authority to give its opinion on such application. The Commission may also hear the parties before it gives a ruling on the application filed by the taxpayer. Having done this, the Commission may allow the taxpayer to lodge appeal out of time where the Commission is satisfied that the taxpayer was not able to lodge the appeal within the 30 days' time limit owing to force majeure as defined by the Civil Code of Ethiopia. ${ }^{93}$

\subsection{The pay-to-play rule: Advance tax deposit requirement}

The precondition of advance deposit has been an important component of the Ethiopian tax appeal system starting from the early 1940s. ${ }^{94}$ When the draft FTAP was tabled for discussion, the amount of tax to be paid as precondition to appeal was one of the most contentious issues. Taxpayers seriously argued that since strict application of this rule was an obstacle to access to justice, it should be reduced from the hitherto $50 \%$ of the tax assessed (including basic tax, penalty and interest) to something like $25 \%$ or $30 \%$ of the disputed amount of basic tax (F:6 \%-nC) excluding penalty and interest. ${ }^{95}$ Taxpayers also argued that such obligation should not only be met by cash payment. Rather, they argued, the tax authority should accept other guarantees such as surety, mortgage, pledge or financial guarantee bond by citing the practice of various jurisdictions. ${ }^{96}$

The representatives from the Tax Authority, on the other hand, argued that reducing the amount of the hitherto $50 \%$ of disputed amount of tax to the one proposed by the taxpayers would be detrimental to government revenue and hence to the developmental endeavors of the country. They also argued that accepting other forms of securities in lieu of cash would be to the detriment of the government on two grounds. First, if real or personal securities were accepted in place of cash, government would lose revenues

93 See Civil Code of the Empire of Ethiopia, Proc. No.165/1960, Neg. Gaz. Year 19, No. 2. Art. 1793 defines force majeure as "the unforeseeable act of a third party for whom the debtor is not responsible", or "an official prohibition preventing the performance of the contract", or "natural catastrophe such as earthquake, lightning or floods", or "international or civil war", or "the death or serious accident or unexpected serious illness of the debtor."

${ }^{94}$ See Aschalew, cited above at note 9, pp. 202-208. See also the tax laws enumerated under foot note number 24 above.

95 The author observed this as he was one of the participants when the draft FTAP was tabled for discussion.

${ }^{96}$ Ibid. 
Tax Appeal Proceedings before the Federal Tax Appeal Commission in Ethiopia... 219

that it can use without considerable delay; secondly, accepting real securities such as pledge and mortgage would be inconvenient to the tax authority since administration and/or alienation of such properties would be a difficult task requiring the mobilization of additional resource and personnel. ${ }^{97}$

When the draft proclamation was finally presented to the HoPR, the House determined that a taxpayer who wants to lodge an appeal to the FTAC should pay $50 \%$ of the basic tax in dispute. However, contrary to its immediate predecessors, FTAP stipulates that the 50\% advance tax payment applies only on the basic tax and not to the additional late payment interest and penalty. This is an appreciable improvement because before the coming into force of this Proclamation, the penalty and interest would constitute an amount of money usually higher than the basic tax thereby making the obligation of the taxpayer very much arduous, ${ }^{98}$ and in effect, causing serious impediment to access to justice. ${ }^{99}$

Despite such improvement, the 50\% deposit requirement and the fact that such money should be paid only in cash have remained sources of discontent to taxpayers. ${ }^{100}$ Professionals and taxpayers interviewed argued that the percentage should be reduced and there should be exceptional circumstances where a taxpayer can lodge an appeal by producing real securities. There should also be circumstances where an aggrieved taxpayer may lodge an appeal to the FTAC without paying tax advance deposit or furnishing a security where it is proved that the appellant does not have any means to meet the deposit requirement since justice is not a commodity that has to be bought by money. ${ }^{101}$

I argue that although the $50 \%$ amount of deposit may be tolerable in the interest of the general public, demanding taxpayers to meet this obligation through payment of cash under all circumstances seems to be unjust. This is because under the Ethiopian situation there are taxpayers who face financial liquidity problems to deposit this amount within 30 days from the date of the decision of the tax authority.

\footnotetext{
${ }^{97}$ Ibid

98 This problem was partly attributable to the fact that the amount of interest to be paid by a taxpayer was not capped which means that interest would continue to count regardless of the length of time the final tax liability was determined. In addition, under the FTAP, the amount of interest is capped taking into account the problem that taxpayers were facing before the coming into force of this Proclamation.

${ }^{99}$ See Aschalew, cited above at note 9, pp.218-219.

${ }^{100}$ Interviewees mentioned at note 31 above.

${ }^{101}$ Ibid.
} 


\subsection{Filing notice of appeal to the FTAC}

A taxpayer dissatisfied with an objection decision made by the Tax Authority ${ }^{102}$ can challenge that decision by filing a notice of appeal ${ }^{103}$ to the FTAC having met the above conditions of appeal. ${ }^{104}$ A notice of appeal is to be filed by the appellant or his legal representative since it is only the appellant or his representative who is a real party in interest in the outcome of the case as provided under Art. 32 of the Civil Procedure Code of Ethiopia. The notice of appeal is, inter alia, required to contain detailed facts on which the appeal is based, the factual and legal reasons for appeal, the copy of the appealable decision, the name of an organ of the tax authority that rendered the appealable decision, documents which serve as evidence and name of witnesses and their addresses, memorandum of association and articles of association where the appeal is filed by a legal person and evidence which shows half of the disputed amount of tax is paid. ${ }^{105}$

When a notice of appeal is submitted to the FTAC, the Commission scrutinizes the notice of appeal to check whether it has met the requirements provided by law. The notice of appeal is rejected where it fails to meet the requirements. ${ }^{106}$ If we stick to the approach of the Civil Procedure Code, the registrar is empowered to scrutinize the memorandum of appeal with regard to formal requirements while the judge is empowered to examine for substantive requirements. ${ }^{107}$

Contrary to what the Civil Procedure Code provides, the Directive issued by the PM states that such power is reserved to the Registrar of the Commission or in his absence to a judge of the Commission. ${ }^{108}$ Regarding formal requirements, it is appropriate to give such power to the registrar since the fulfillment or otherwise of the formal requirements cannot be as such controversial whereas giving the power to the registrar to determine

${ }^{102}$ It is to be noted that the Review Department makes a recommendation. The final decision is made by Minister at head office level and by the manager at branch levels. In the final analysis, an appealable decision is not the decision of the Review Department; rather, an appealable decision is the decision of the tax authority.

${ }^{103}$ Note that this term is equivalent to memorandum of appeal. However, the FTAP uses notice of appeal. Such usage is influenced by the Australian tax laws as the draftsperson of the FTAP, Professor Lee Burns, came from Australia.

${ }^{104}$ FTAP, cited above at note 10 , Art. 56(1).

${ }^{105} \mathrm{Id}$, Art. 88 cum Directive on the Working Procedures of the Tax Appeal Commission, issued by the Prime Minister, Amharic, 2011 E.C, Art.5 \&6.(Hereinafter cited as PM Directive)

106 Id, Art.7.

${ }^{107}$ Civil Procedure Code, cited above at note 92, Art.229-231.

108 PM Directive, cited above at note 105 , Arts. 7 \& 8. 
whether the notice of appeal contains both factual and legal grounds of appeal is inappropriate. This is because it is not easy for the registrar to determine at the filing stage whether an appeal contains factual and legal grounds. Hence, granting such power to a single registrar is detrimental to the interest of the appellant who can encounter an erroneous rejection of his appeal even if the registrar might be a legal professional. ${ }^{109}$

Needless to say, tax cases are usually complicated containing layers of facts and legal issues making it difficult for the registrar to determine in advance whether or not the appeal has factual and/or legal grounds. The registrar should thus only be allowed to determine whether formal requirements of a notice of appeal are satisfied; and the power to determine whether the notice of appeal contains factual and legal grounds should be left to the judges of the Commission.

This argument can be substantiated by the relevant provisions of the Ethiopian Civil Procedure Code since the Directive Issued by the Prime Minister has made cross-reference to the Code. ${ }^{110}$ According to the Civil Procedure Code, a statement of claim is rejected by the registrar where it fails to meet formal requirements specified in the Code while the power to make substantive investigation on the statement of claim is reserved to the judge. ${ }^{111}$ The judge makes substantive examination on the statement of claim to check whether the statement of claim contains cause of action and whether it is within the jurisdiction of the court. By doing so, the judge may reject the statement of claim where he believes that it does not disclose a cause of action and if the particulars of the statement of claim show that the suit is outside the jurisdiction of the court. ${ }^{12}$

The Directive stipulates that if a notice of appeal is rejected by the Registrar or a judge of the Commission, the appellant has the right to lodge a complaint to the President of the Commission. ${ }^{113}$ If the President is satisfied that the complaint of the appellant is correct, he would dismiss the ruling of the registrar or the judge and would order that the notice of appeal be filed.

${ }^{109}$ At the FTAC, the author observed that the registrar of FTAC at the time of revising this work (September, 2020) is a legal professional though he does not have expertise in Ethiopian tax laws. He did not have any exposure to the tax laws of Ethiopia as he was an advisor of the Attorney General before his departure to the FTAC.

${ }^{110}$ Id, Art.18.

${ }^{111}$ Civil Procedure Code, cited above at note 92, Art. 229.

112 Id., Art. 231.

${ }^{113}$ PM Directive, cited above at note 105, Art. 8(4). 
On the other hand, if the President is of the view that the rejection of the notice of appeal by the registrar or the judge is correct, he should immediately notify the appellant that his complaint is rejected along with the reasons justifying the rejection. ${ }^{114}$ In this case, the appellant has the right to file a new notice of appeal by remedying the problems which caused the rejection of appeal within the 30 days of appeal counted from the date of receipt of the appealable decision. ${ }^{115}$

The question, however, is: what if the 30 days' time limit for appeal lapses while the appeal is being examined by the President of the Commission? The FTAP, the FTAR and the Directive under consideration do not offer answer to this question. Hence, where such problem is encountered, we have to resort to a workable interpretation of the silence of the law. Having in mind the prime purpose of procedural rules, the healthy approach is to allow the appellant to file new notice of appeal within a certain period of time starting from the approval of the rejection of the first notice of appeal by the President of the Commission. Unless we follow this line of interpretation, the appellant's access to justice cannot be ensured.

\subsection{Reply to the notice of appeal and the counter-reply}

Under the Civil Procedure Code of Ethiopia, a respondent is not allowed to file a reply as of right unless the court orders him to do so. ${ }^{116}$ However, Art. 89(1) of the FTAP provides that "when the notice of appeal is served on the Tax Authority, it has to file its reply to the Commission within 30 days of being served on the notice of appeal or within such further time as the Commission may allow."

With regard to extension of time for the appellant, the FTAP envisages that the Commission would issue a directive that would provide the grounds of extension of the 30 days' time limit. ${ }^{117}$ However, it does not indicate whether the Commission would issue a directive regarding extension of time of reply or whether the extension of time can be granted to the Authority by the Commission. Hence, the FTAP should have defined the grounds of extension of time for filing an appeal and reply by the Commission which would be equally applicable to the Tax Authority and the taxpayer thereby ensuring procedural equality of the parties.

With regard to contents of the reply, Art. 89(1) of the FTAP stipulates that the reply is required to contain a statement setting out the reasons for

\footnotetext{
${ }^{114}$ Id, Art. 8(5).

${ }^{115}$ Id, Art. 7(2).

${ }^{116}$ Civil Procedure Code, cited above at note 92, Arts 338-339.

${ }^{117}$ FTAP, cited above at note 10, Art. 88(4).
} 
Tax Appeal Proceedings before the Federal Tax Appeal Commission in Ethiopia... 223

making the appealable decision made by the Authority and any other document relevant to the Commission's review of the decision against which an appeal is made to the Commission. Art. 89(2) of the Proclamation has made it clear that if the statement filed by the Tax Authority under subarticle 1 of the same article does not contain statement of reason, the Commission has the power to require the Authority by a written notice to file a further statement of reason within the time determined in the notice.

This sub-article seems to suggest that the law is more favorable to the Tax Authority because if the taxpayer appellant fails to state reasons in his notice of appeal, his appeal would be rejected instead of getting the chance for amendment by the initiation of the Commission. Although the Tax Authority litigates before the Commission representing public interest, the same procedural rules should be applied to ensure that both parties are fairly treated $^{118}$ as we cannot claim that public interest can be treated more favorably than the interests of private individuals in tax proceedings conducted before an appeal tribunal. ${ }^{119}$

Although the FTAP is silent on whether the appellant taxpayer has the right to submit a counter-reply to the reply submitted by the Tax Authority, the Directive issued by the PM states that the appellant taxpayer has can file a counter-reply if he wishes to do so. ${ }^{120}$ If the appellant taxpayer opts to file a counter-reply, he has to submit it on the date determined by the Commission which cannot be less than 10 days reckoned from the date of submission of the reply by the Tax Authority. ${ }^{121}$ The 10 days' time limit seems to be short since there might be circumstances where giving a counter-reply may require careful analysis of the reply filed by the Tax Authority and writing a well-considered counter-reply that can successfully discredit the reply of the Tax Authority. Therefore, instead of determining such a short period of time, the Directive should have left it to the Commission so that it may determine the time on case by case basis. ${ }^{122}$

118 See Tom R. Tyler (1988), 'What is Procedural Justice - Criteria Used by Citizens to Assess the Fairness of Legal Procedures,' Law and Society Review, Vol. 22, p. 105.

119 See Paul Stancil (2017), 'Substantive Equality and Procedural Justice, 'Iowa Law Review, Vol.102, No.4, p. 286.

${ }^{120}$ PM Directive, cited above at note 105, Art. 10(1).

${ }^{121} \mathrm{Id}$, Art. 10(2).

${ }^{122}$ In ordinary civil appeal proceedings, the appellant has the right to file a counter-reply where the respondent files a reply up on the permission of the court and the time of filing a counter-reply is to be determined by the court taking into account the complexity of the case and other relevant circumstances; See Civil Procedure Code, cited above at note 91, Art.338. 


\section{Appellate Proceeding before the FTAC}

\subsection{Appearance of the parties and effects of non-appearance}

Under the Civil Procedure Code of Ethiopia, if an appellant or both the appellant and the respondent fail to appear at the time of hearing, the court shall dismiss the appeal. If, on the other hand, the respondent fails to appear, the appeal will continue ex parte. ${ }^{123}$ With regard to tax appeal proceedings conducted by the FTAC, the FTAR states that "if the appellant fails to appear in person or be represented at a hearing of the appeal, the Commission may dismiss the appeal." 124 As compared to the Civil Procedure Code, the Regulation seems to be favorable to a taxpayer (appellant) as it gives the Commission a discretion to or not to dismiss the appeal despite the non-appearance of the appellant at the time of the hearing of the appeal. ${ }^{125}$ The Directive issued by the PM, on the other hand, states that where the appellant or his representative fails to appear before the Commission at the time of hearing, the Commission may give one adjournment. If the appellant fails to appear on the adjourned date, the Commission is empowered to dismiss the appeal. ${ }^{126}$

There is inconsistency between the Regulation and the Directive because the former states that the Commission may dismiss the appeal where the appellant fails to appear at the time of hearing, while the latter enables the Commission to adjourn the hearing for one more time irrespective of the ground of non-appearance of the appellant. But because the Directive is below the Regulation in the hierarchy of laws, ${ }^{127}$ the Commission is dutybound to adhere to what the Regulation provides i.e. the FTAC has the

${ }^{123}$ Civil Procedure Code, cited above at note 92, Art. 69(2).

${ }^{124}$ Federal Tax Administration Regulation, Reg.No.407/2017,Fed.Neg.Gaz., Year 22,No.79, Art.10(2).(Hereinafter cited as FTAR)

${ }^{125}$ Under the Civil Procedure Code, the court is obliged to dismiss the appeal if the appellant fails to at the time of hearing the appeal. The court does not have any discretionary power not to dismiss the appeal as a matter of exception. This means that the Civil Procedure Code has used an objective standard while the FTAR has used a subjective standard.

${ }^{126}$ PM Directive, cited above at note 105, Art. 12(1).

${ }^{127}$ Under the Ethiopian legal system, the Constitution is supreme to all laws followed by proclamations that are issued by HoPR and then by regulations that are issued by the Council of Ministers. Directives come at the bottom of hierarchy of laws since they are issued either by the Prime Minister or any other administrative body of the Federal Government for the proper implementation of proclamations and/or regulations as circumstance so demand. See Ayele Bogale (1999), Hierarchy of law with in the present federal legal structure of Ethiopia, LL.B thesis, unpublished, Faculty of Law, Addis Ababa University. 
Tax Appeal Proceedings before the Federal Tax Appeal Commission in Ethiopia... 225

discretion to dismiss or not to dismiss the appeal where the appellant fails to appear at the hearing.

Although non-appearance of an appellant for no apparent reason at the time of hearing the appeal has to be seriously sanctioned by dismissing the appeal, the law gives room where the dismissed appeal may be reinstated if the appellant is able to show to the Commission that his non-appearance was attributable to a factor beyond his control. This is appreciable because it would be extremely unfair to punish an appellant who was prevented from appearing before the Commission at the time of hearing by a factor which he could not control. ${ }^{128}$ The Civil Procedure Code also states that an appeal dismissed by the court may be reinstated where the appellant shows that he failed to appear owing to good cause even though the Code does not indicate the constituent elements of good cause. ${ }^{129}$

The Tax Authority is also required to appear before the Commission at the time of the hearing of the appeal as provided under the Directive. ${ }^{130}$ If the Tax Authority fails to appear, the Commission may adjourn the hearing for another day ${ }^{131}$ and if the Tax Authority again fails to appear at the second hearing, the Commission conducts the hearing ex parte. ${ }^{132}$ A question arises whether the Tax Authority can request the setting aside of the hearing and plead for rehearing of the case by showing that it (the Tax Authority) failed to appear at the time of hearing owing to force majeure.

The FTAR and the Directive issued by the PM are silent on this issue, and we can argue that the Tax Authority has the right to get an order of ex parte proceeding set aside where it shows to the Commission that it was prevented from appearing on the hearing date because of force majeure or any other sufficient cause. In fact, this argument can be substantiated by the fact that the Directive issued by the PM has made cross-reference to the Civil Procedure $\operatorname{Code}^{133}$ which allows the setting aside of ex parte proceedings where a respondent was not able to appear at the time of hearing an appeal because of good cause. ${ }^{134}$

In order to ensure equality of arms of the litigants, the opportunity available to the taxpayer should equally be available to the Tax Authority.

\footnotetext{
${ }^{128}$ PM Directive, cited above at note 104, Art. 12(3).

${ }^{129}$ Civil Procedure Code, cited above at note 92, Art. Art. 74(2).

${ }^{130}$ PM Directive, cited above at note 104, Art. 13(1).

${ }^{131} \mathrm{Id}$, Art. 13(2).

132 Id, Art. 13(3).

133 Id, Art.18.

${ }^{134}$ Civil Procedure Code, cited above at note 92, Art. 74(1).
} 
This is because "procedural safeguards must be neutral and impartial in order to be fair. That is, they must provide a forum in which neither party has an inherent institutional advantage over the other."135 The problem, however, is that the law has not stated the grounds which can be accepted by the Commission to set aside dismissal or ex parte order. This shows that the litigants are left to the discretionary power of the Commission.

\subsection{Hearing procedure}

The right to be heard is an indispensable element of fairness and procedural due process of law. ${ }^{136}$ It is one of the fundamental elements of natural justice, ${ }^{137}$ and it is also an important concern of national constitutional norms and human rights instruments. ${ }^{138}$ Art. 10 of the Universal Declaration of Human Rights (UDHR) has made it clear that everyone is entitled to a fair and public hearing by an independent and impartial tribunal in the determination of his rights and obligations. Moreover, Art. 14(1) of the International Covenant on Civil and Political Rights (ICCPR) states that "every person is entitled to a fair and public hearing by a competent, independent and impartial tribunal."

The jurisprudence of the Human Rights Committee (HRC) also demonstrates that litigants are entitled to a fair and open hearing in administrative proceedings and before ordinary courts of law. ${ }^{139}$ Attention is given to an open hearing because it is this kind of hearing that is capable of enabling the public to observe that justice is actually done. ${ }^{140}$ According to Bayles, an open hearing is an indispensable instrument to control arbitrariness on the part of the decision-makers and it helps the public to correct injustice which may result from the unjust application of just rules. ${ }^{141}$

In Ethiopia, the FDRE Constitution does not have a provision which expressly provides that litigants in civil proceedings in general and administrative proceedings in particular are entitled to an open hearing. Yet,

${ }^{135}$ Leonard S. Rubenstein (1976), ' Procedural Due Process and the Limits of the Adversary System,' Harvard Civil Rights-Civil Liberties Law Review, Vol.11, P.58.

${ }^{136}$ Edward J. Eberle (1987), 'Procedural Due Process: The Original Understanding,' Constitutional Commentary,Vol.4, No.2, p.339.

${ }^{137}$ P. P. Craig (2003), Administrative Law, Sweet and Maxwell, p.407.

${ }^{138}$ Michael D. Bayles (1990), Procedural Justice, Kluwer Academic Publishers, pp.3940.

${ }^{139}$ Noel Dias and Roger Gamble (2007), 'Independence, Impartiality and Scrutiny: The Essence of Fair Trial Protection', Sri Lanka Journal of International Law, Vol. 19, p. 302.

${ }^{140}$ Bayles, cited above at note 138, p. 42 .

${ }^{141}$ Ibid. 
Tax Appeal Proceedings before the Federal Tax Appeal Commission in Ethiopia... 227

it states that international instruments to which Ethiopia is a party are part and parcel of the Ethiopian laws. This renders Art. 14(1) of the ICCPR (that has guaranteed the right to an open hearing) applicable in Ethiopia as though it were a law issued by the Ethiopian Parliament.

Open hearing is one of the most important procedural requirements (in all proceedings including appellate proceedings) under the Ethiopian Civil Procedure Code. This is applicable to tax cases by virtue of the crossreference made to it by the PM Directive. ${ }^{142}$ The FTAP also indicates that taxpayers are entitled to an open hearing even though there is no specific provision which expressly states that taxpayers are entitled to be heard in an open setting. ${ }^{143}$ Furthermore, the Directive issued by the PM recognizes the right of taxpayers to an open hearing. ${ }^{144}$

However, there are gaps in the course of the hearing because the judges do not provide adequate time to the litigants during the hearing. ${ }^{145}$ Lack of proper recording at the time of the hearing erodes trust of the litigants. ${ }^{146}$ Moreover, the hearing is not an open hearing owing to problem of space as the FTAC does not have its own building. ${ }^{147}$

\subsection{Burden of proof}

Administrative tribunals are quasi-judicial adjudicative bodies which entertain cases within their competence and render binding decisions. In order to render an acceptable and binding decision, administrative agencies make use of evidence produced by the parties and evidence that may be produced under their order in the interest of justice. ${ }^{148}$ In the normal course of circumstances, burden of proof in administrative agencies is in line with the burden of proof employed in civil proceedings, i.e.. the one who alleges the existence of a certain fact has to prove that the fact exists. However, in tax cases, the burden of proof lies on the taxpayer in many jurisdictions

142 PM Directive cited above at note 105, Art.18.

${ }^{143}$ FTAP, cited above at note 10, Art.90(1). This sub-article states that the president of the Commission shall assign a member or members to the hearing of an appeal as the president considers appropriate having regard to issues raised by the appeal.

144 PM Directive, cited above at note 105, Art. 11(1).

${ }^{145}$ Interview with Semaw Nigatu, Consultant and Attorney at law, September 24, 2020.

146 Interveiw with Amare Lakew, Private Tax Accountant and Tax consultant, September 18, 2020.

${ }^{147}$ Interview with Girma Taffese, Tax advisor of East Africa Holding Company, September 30, 2020.

148 See generally James E. Youngdahl (1960), 'Rules of Evidence in Administrative Proceedings,' Arkansas Law Review, Vol.15, pp.138-159. 
although there are exceptional circumstances where burden of proof may be shouldered by the tax authorities. ${ }^{149}$

In Ethiopia, the FTAP provides that burden of proof lies on the taxpayer in proceedings before the FTAC. ${ }^{150}$ Although issues relating to burden of proof in taxation basically arise at the internal review stage in Ethiopia, the FTAC is not confined to the record sent to it by the Tax Authority. Rather, it has the power to see a case de novo thereby enabling taxpayers to have the right to adduce any evidence at this stage which is relevant to the case. Hence, the taxpayer bears the burden of proof, at this stage too, by producing admissible and relevant evidence to the Commission.

The problem, however, is that there are no comprehensive rules ${ }^{151}$ in Ethiopia that help us determine the relevance and admissibility of evidence in ordinary civil proceedings in general and tax proceeding in particular. Therefore, determining the relevance and admissibility of evidence in tax proceedings is left to the judges of the Commission. Appellants in Ethiopia are thus under the discretion of the judges of the Commission regarding the relevance and admissibility of their evidence. There are many circumstances whereby taxpayers are condemned to pay whatever is decided by an auditor due to their inability to adduce evidence particularly where tax is determined by estimation upon the rejection of books of accounts kept by them. ${ }^{152}$

The other issue that arises in relation to burden of proof relates to the types of evidence that may be produced by the taxpayers before the Commission. The FTAP and the FTAR have not addressed this issue. Yet, the PM Directive is of some help to taxpayers since it contains few provisions dealing with types of evidence that can be adduced by an appellant taxpayer. In this regard, Art. 15 of the Directive expressly states that an appellant taxpayer can adduce both oral and documentary evidence.

149 See M. Moran (1987), 'The Presumption of Correctness: Should the Commissioner be Required to Carry the Initial Burden of Production,' Fordham Law Review Vol.55, No.6, pp.1087-1108; John R. Gardner and Benjamin R. Norman(2003), Effects of the Shift in the Burden of Proof in the Disposition of Tax Cases, Wake Forest Law Review,Vol.38, No.4, pp.1357-1358.

${ }^{150}$ Note that Art. 59 of the FTAP which has stated that burden of proof lies on the taxpayer is applicable both to the internal review stage and appellate proceeding before the Commission.

${ }^{151}$ It has to be clear, however, that are evidence rules scattered in various laws of the country such as the Law of Contracts, Family Law, Law of Succession, Law of Property and so on.

${ }^{152}$ Interview with Tekka Mehari cited above at note 56; interview with Teferra Lemma, cited above at note 100; interview with Dawit Teshome, consultant and attorney at law, September 17, 2020. 
Tax Appeal Proceedings before the Federal Tax Appeal Commission in Ethiopia... 229

However, there are a number of issues that arise in relation to oral testimony and documentary evidence. As the law stands now, it is not easy to determine various issues relating to evidence including the standard of proof that is used in tax proceedings. ${ }^{153}$

In spite of these gaps, the PM Directive enables the Commission to order the production of evidence that may be useful for the proper determination of the appeal. ${ }^{154}$ It states that the Commission may order the parties to produce (to the Commission) books of accounts which they deem by agreement are key to the disposition of the dispute, ${ }^{155}$ to indicate to the Commission documents, decisions or testimonies which are in the hands of other bodies (having lawful authority to hold such documents, decisions or testimonies) and to produce expert, technical or scientific evidence that are relevant to the case. ${ }^{156}$

Moreover, the Commission has the power to order any person to produce any document or to appear in person and give testimony where doing so is necessary in the interest of justice. ${ }^{157}$ The Directive also empowers the Commission to order any institution to produce a document or to send an expert or send a result of investigation to the Commission. ${ }^{158}$ Therefore, these powers granted to the Commission by the Directive in relation to production of evidence are helpful to the taxpayer. Such powers are also helpful to promote the interest of the Tax Authority (and hence public interest) as evidence which was not produced by the Tax Authority may be produced by the order of the Commission.

\section{Decision of the FTAC and Its Enforcement}

\subsection{Time limit to render a decision}

Before the coming to force of the FTAP, no tax law of Ethiopia stipulated that the FTAC was bound to make a decision within a certain period of time reckoned from the time of filing the appeal. ${ }^{159}$ It is indeed commendable that the FTAP requires the FTAC to render its decision within 120 days from the

\footnotetext{
${ }^{153}$ Normally, we expect that the preponderance of evidence may be used as tax litigations are cognate to civil litigations.

${ }^{154}$ PM Directive, cited above at note 105, Art. 15(3).

${ }^{155}$ Id, Art. 16(1.d).

${ }^{156} \mathrm{Id}, 16(1 . \mathrm{e})$.

${ }^{157}$ Id, Art. 16(1.f).

158 Id, Art. 16(2).

${ }^{159}$ Aschalew, cited above at note 9, p.226.
} 
notice of appeal filed with the Commission. ${ }^{160}$ Hence, this is an important departure made by the FTAP since it helps taxpayers get timely decision. This saves money, energy and time of the taxpayer and reduces the anxiety of the taxpayer. Setting a time limit makes the Commission discharge its duties responsibly and with a sense of accountability.

Moreover, if the decision is made in favor of the taxpayer appellant, the appellant gets the refund of the $50 \%$ of the disputed amount of tax paid at the time of filing the appeal. This safeguards the taxpayer from risks such as inflation which erodes the purchasing power of money. ${ }^{161}$ In practice, the FTAC tries to render its decision within the 120 days' time limit although there are circumstances where a case takes several months. There are even cases that extend to a year or two years. According to members of the FTAC, failure to decide within the 120 days' time limit is basically attributable to complexity of cases and inadequate number of judges. ${ }^{162}$

As a matter of exception, the FTAP states that the President of the Commission may extend the 120 days limit for an additional period not exceeding 60 days having regard to the complexity of the issues and the interest of justice. ${ }^{163}$ The President of the FTAC has to inform the extension to the parties by a written notice. The problem, however, is that because the two grounds which justify extension of time -complexity and interest of justice- are susceptible to subjective standards, the President has a discretion to extend the period of deciding the case even if these grounds do not exist. Therefore, one can argue that in the absence of clear and specific guidelines that help to measure the complexity or otherwise of a tax cases and as to when the interest of justice requires extension of time, the President may arbitrarily extend the period.

No sanction is imposed on the Commission if it fails to decide a case within the 120 days or even within the additional 60 days. Rather, the Proclamation states that the failure of the Commission to comply with the requirement to decide within the 120 days' time limit does not affect the validity of the decision of the Commission. Therefore, the provision of a time limit for the decision of the appeal becomes meaningless since a

${ }^{160}$ FTAP, cited above at note 10, Art. 91(2).

${ }^{161}$ Interview with Husamudin Seifu, cited above at note 100; interview with Wondiye Girma, cited above at note 100.

${ }^{162}$ Interview with Serkalem Eniyew, cited above at note 30.

${ }^{163}$ FTAP, cited above at note 10, Art. 91(3). This means that the President does not extend the period for deciding the appeal for no apparent reason. Rather, he has to show to the parties that the extension is justified because of the complexity of the issues being litigated and the interest of justice so requires the extension. 
Tax Appeal Proceedings before the Federal Tax Appeal Commission in Ethiopia... 231

decision rendered by the Commission remains valid even though it is made after a long period of delay without justification.

\subsection{Decision of the FTAC}

For the decision of the Commission to be valid and binding, it has to meet certain procedural requirements which include quorum, decisional power and content. The PM Directive states that there shall be a quorum where three judges (out of the five judges who constitute the panel of the Commission) are present and decision is to be made by majority vote. Where there is a tie, the decision supported by the chairperson of the panel is the decision of the Commission. ${ }^{164}$

Regarding the decisional power of the Commission, the FTAP stipulates that the Commission has the power to "affirm, reduce or otherwise amend the tax assessment or remit the tax assessment to the Tax Authority for reconsideration where the appeal relates to a tax assessment."165 However, where the Commission is of the view that the amount of tax assessed should be increased, it (the Commission) shall remand the case to the Tax Authority for reconsideration in accordance with the directions of the former. ${ }^{166}$ Where an appeal to FTAC relates to any other appealable decision (non-assessment appeal), the Commission has the power to affirm, vary, set aside the decision or remand the case to the Tax Authority for reconsideration in ascendance with the directions of the Commission. ${ }^{167}$

A question is likely to arise with regard to rationale behind remanding the case to the Tax Authority where the Commission finds that the tax assessment can be possibly increased. It may be argued that since the appellant lodges an appeal to the Commission for a total avoidance or reduction of his tax burden, it would be unfair to increase such burden by an appellate body which is not created to fix the tax liability of the taxpayer. It may also be argued in support of the FTAP because tax law is a matter of public policy and the Commission cannot be confined to the issues raised by the parties. If the Commission realizes that tax should be increased taking into account the applicable provisions of tax legislation and the facts verified through the proceedings, it should not remain silent since doing so would be detrimental to public interest. For example, the Tax Appeal Tribunal in Belgium is not bound by the arguments raised by the parties. Rather, it has

\footnotetext{
${ }^{164}$ PM Directive, cited above at note 105, Art.12.

${ }^{165}$ FTAP, cited above at note 10, Art. 91(5).

${ }^{166}$ Id, Art. 91(6).

${ }^{167}$ Id, Art. 91(7).
} 
the power to decide on any other relevant ground which may result in increment of the tax liability of the appellant although an appellant lodges an appeal seeking lower tax than the one decided by the tax authority. ${ }^{168}$

With regard to the content of the decision, Art. 91(9) of the FTAP states that the decision of the Commission should be "made in writing and contain the reasons for the decision, the findings on material questions of fact and reference to evidence or other material on which findings of the Commission are based."169 Because the FTAC gives binding decision which affect citizens, it has to give reasons. As Kendrick Lo notes, if we aspire to govern society by the rule of law, there should be ethos of justification in decision giving. ${ }^{170} \mathrm{He}$ states that, where society is marked by justification, an exercise of public power is only appropriate where it can be justified to citizens in terms of rationality and fairness. ${ }^{171}$ It is also argued that giving reasons by administrative tribunals enhances the prevalence of rule of law since it promotes transparency and accountability. ${ }^{172}$ In addition, giving reasons is a guarantee for better decisions by administrative tribunals. ${ }^{173}$ As Lo noted:

... the actual process of writing reasons forces decision makers to pay conscious attention to the logic underlying a decision, to confirm there is indeed a rational connection between an outcome reached and the basis for that outcome. It is conceivable that those decision makers, while immersed in the writing process, may come to realize that they cannot articulate an intelligible part of reasoning that leads to the anticipated result. ${ }^{174}$

According to Bayles, express statement of reasons is indispensable because it prevents arbitrariness and incorrect judgments, ensures uniformity of decision and helps a litigant to know why a certain decision was given and whether an appeal is reasonable. ${ }^{175}$ It is to be noted that the right of appeal or resort to judicial review hinges on the ability to show the decision-

${ }^{168}$ Caroline P. Docclo (2019), 'Belgium', in Simon Whitehead (ed.), Tax Disputes and Litigation Review, Law and Business Research, p. 23.

${ }^{169}$ FTAP, cited above at note 10, Art. 97(8).

${ }^{170}$ Kendrick Lo (2018), 'When Efficiency Calls: Rethinking the Obligation to Provide Reasons for Administrative Decisions,' Queen's Law Journal, Vol.43, p.348.

${ }^{171}$ Ibid. See also Beverley McLachlin (1998), 'The Roles of Administrative Tribunals and Courts in Maintaining the Rule of Law,' Canadian Journal of Administrative Law and Practice, Vol.12, pp. 174-75.

172 Ibid.

${ }^{173}$ See generally, Martin Shapiro (1992), 'The Giving Reasons Requirement,' University of Chicago Legal Forum, Issue No. 1, Article 8, pp. 179-220.

${ }^{174}$ Lo, cited above at note 170, p.351.

${ }^{175}$ Bayles, cited above at note 138, P.75-76. 
Tax Appeal Proceedings before the Federal Tax Appeal Commission in Ethiopia... 233

maker's error. ${ }^{176}$ In practice, the FTAC tries to give reason for its decisions although its various decisions lack adequate legal analysis. Rather, the decisions of the FTAC are usually filled with verbatim reproduction of written statements of the parties. In most decisions, the reasoning part occupies very small space without adequate legal reasoning and analysis. ${ }^{177}$

\subsection{Execution of the Commission's decision}

The FTAP provides that the decision of the Commission is ready for execution starting from the date of the decision or on such other date as may be specified by the Commission in the notice of the decision. ${ }^{178}$ If decision is rendered in favor of the Tax Authority, the Authority moves forward for the implementation of the decision with a view to collecting the remaining tax, ${ }^{179}$ the penalty and the interest determined by the Tax Authority. ${ }^{180}$ The Ethiopian Tax Authority has the power to execute the decision made in its favor by the FTAC, ${ }^{181}$ and it executes the decision starting from the end of the 30 days (reckoned from the date of the decision of the Commission) appeal period within which the taxpayer can lodge an appeal to the $\mathrm{FHC}^{182}$ in matters relating to legal issues. To this end, the Tax Authority is empowered to take various measures such as attaching and selling of the assets of the taxpayer, collecting money from third parties that are due to the taxpayer, and ordering banks to transfer money to the Tax Authority from the taxpayer's account. ${ }^{183}$

${ }^{176}$ Lo, cited above at note 170 , p. 352.

${ }^{177}$ Author's personal observation of the decisions of the FTAC.

${ }^{178}$ FTAP, cited above at note 10, Art. 91(10). Art. 91(8) has stated that the commission is bound to give the copy of its decision to each party within seven days of the making of the decision.

${ }^{179} 50 \%$ of the basic tax is to be paid before lodging the appeal to the Commission since such obligation is an inescapable precondition to file a notice of appeal with the Commission.

${ }^{180}$ It is good to note that when a taxpayer lodges an appeal to the Commission, penalty and interest remain unpaid until the fate of the basic tax is determined by the Commission.

${ }^{181}$ FTAP, cited above note 10, Art.38. The Tax Authority has been enjoying such power of execution since 2002 to date although such power was seriously contested at that time on the ground that the rights of taxpayers might be affected in the course of execution of tax decisions without any judicial control. It was even argued that granting such power to the Tax Authority is an act of stripping judicial power. See for instance Yared, cited above at note 42, p.147.

${ }^{182}$ FTAP, cited above at note 10, Art. 38(2.b)

${ }^{183}$ Id, Arts. 38-48. 
In the course of execution, the taxpayer may be aggrieved by the action of the Tax Authority such as the valuation of an asset, the manner in which public auction is announced and conducted, the manner and type of attachment of a property and the way the attached property is sold. A question arises whether the taxpayer can lodge an application to the FTAC that rendered the decision or whether the taxpayer is required to file a fresh application to the Review Department. ${ }^{184}$ Although there was a suggestion at the drafting stage of the FTAP that the draft include a provision dealing with the resolution of disputes arising at the time of execution of a tax decision, ${ }^{185}$ the drafters did not include a provision in this regard. This gap has not also been addressed either by the FTAR or the PM Directive which were issued for the proper implementation of the Proclamation. The right of the taxpayer to access to justice is adversely affected owing to absence of clear legal remedy where the taxpayer is affected by the actions of the Tax Authority in the course of execution of a tax decision.

I argue that the taxpayer's right to access to justice is denied at the time of execution of a tax decisions for the following reasons. First, if the taxpayer takes his grievance to the Review Department, the latter may say that its power is confined to tax assessment disputes provided under Art. 2(34) of the FTAP. ${ }^{186}$ Secondly, if the taxpayer takes his grievance to the FTAC, the latter may similarly decline to assume jurisdiction claiming that it is not empowered to entertain disputes arising from the execution of decision by the Tax Authority since execution of tax decision of any sort is within the sole competence of the Tax Authority.

Thirdly, it is very much unlikely that the regular courts accept such dispute since they are not given the power to accept and entertain tax execution cases. Therefore, it follows that the Tax Authority is free from any internal as well as external control if it abuses its power at the time of execution of tax decisions and such gap can also be a fertile ground for

184 These questions were raised before the FTAP was not contemplated since the 2002 tax proclamations of the Federal Government did not address these issues. These issues were also raised when the FTAP was at its drafting stage. In this regard, see Aschalew, cited above at note 9, PP.233-234. See also Aschalew, 'Review of the Ethiopian Income Tax Appeal System', cited above at note 26, p. 40; Misganaw Gashaw, 'The Room for Alternative Dispute Resolution (ADR) Process in Tax Disputes: A Message to the Ethiopian Tax Administrations,' in Yazachew Belew (ed.), The Resolution of Commercial/Business Disputes in Ethiopia: Towards Alternatives to Adjudication? Ethiopian Business Law Series, Vol. 5, p. 49-50.

${ }^{185}$ Aschalew, Review of the Ethiopian Income Tax Appeal System, cited above at note 26, pp.46.

${ }^{186}$ See the enumerations made under note 45 above. 
Tax Appeal Proceedings before the Federal Tax Appeal Commission in Ethiopia... 235

corruption and maladministration. ${ }^{187}$ This problem can only be addressed by allowing the Review Department or the FTAC to accept and decide any dispute arising between the taxpayer and the Tax Authority in the course of execution of a decision.

One may argue that either the Review Department or the Commission should accept such disputes and give a ruling on such issues to ensure the right to access to justice for the taxpayer even at the stage of execution of a tax decision. According to information obtained from a member of the Review Department, taxpayers do not challenge the Tax Authority at this stage, and they rather want to get remedies from the tax authority in its administrative capacity. ${ }^{188}$ An interviewee from the FTAC also stated that taxpayers do not bring such cases to the FTAC. ${ }^{189}$

When the FTAC gives a decision in favor of the taxpayer, the latter has the right to seek execution of the decision pursuant to Art. 95(11) of the FTAP which states that if the decision of the Commission is in favor of the taxpayer, the authority is duty-bound "to take such steps as are necessary to implement the decision, including serving an amended assessment within 30 days of receiving notice of the decision of the Commission." Hence, if the FTAC totally reverses the decision of the Tax Authority, the latter is expected to refund to the taxpayer $50 \%$ of the disputed amount of money deposited by the taxpayer at the time of lodging the appeal to the Commission. On the other hand, if the amount of tax determined by the Tax Authority is reduced by the Commission, the former should refund to the taxpayer an amount of money in accordance with the reduction. In the case of a decision on an appeal not relating to tax assessment, the Tax Authority is expected to execute it in accordance with the terms and conditions of the decision rendered by the Commission.

In case the Tax Authority fails to execute the decision made by the Commission in favor of the taxpayer, the FTAP is silent with regard to the remedies available to the taxpayer. One may argue that the decree-holder (the taxpayer) would remain under the mercy of the Tax Authority for the

${ }^{187}$ It has to be clear that corruption in relation tax administration is a serious problem in Africa. Ethiopia cannot be an exception to this problem either. In this regard, see Belay Worku, Good Governance and Business Tax Administration in Ethiopia: Legal and Practical Problems, LL.M Thesis unpublished, School of Law, Bahir Dar University, June 2014, p.74.

188 Interview with Zewude Damtew, Head of the Review Department of Large Taxpayer, West Addis Ababa Branch, Ministry of Revenues, September 15, 2020.

${ }^{189}$ Interview with Mulugeta Ayalew, cited above at note 30. 
execution of the decision of the Commission. We can also argue that if the FTAC is empowered to make a binding decision on the Tax Authority, the Commission has an undisputable power to order the Tax Authority to execute the former's decisions rendered in favor of the taxpayer. Hence, it follows that if the Tax Authority fails to refund the money to the taxpayer or to execute any other decision of the Commission, the Commission can order the payment of such money from the account of the tax authority or it may order other means of execution towards the payment of the money due to a decree-holder taxpayer. This line of argument can be buttressed by the provisions of the Civil Code of Ethiopia although the FTAP has not made any cross-reference to the Civil Procedure Code. ${ }^{190}$

Unless we follow such line of argument and interpretation of the law, the right of the taxpayer to get a decision executed would be seriously jeopardized while the Tax Authority would remain free from any control and supervision as far as execution is concerned. This problem indeed necessitates a legal provision which expressly stipulates that the FTAC has the power to entertain any execution application filed by a decree-holder taxpayer and give an appropriate order for the timely and proper execution of its decision. An interviewee who is a member of the FTAC stated that in practice, the FTAC executes its own decision where a decree-holder (taxpayer) seeks the assistance of the Commission. ${ }^{191}$ However, the information from other interviews shows that because of the silence of the law, the FTAC does not have the will and the courage to strictly enforce its own decisions unlike regular courts. ${ }^{192}$

\section{Concluding Remarks}

Although tax is a compulsory levy imposed by the government, the power of taxation cannot be exercised arbitrarily. Rather, a modern tax system is expected to be a good tax system as tax maladministration has far-reaching economic, social and political repercussions. One of the critical features of a good tax system is creating a fair tax dispute resolution system which enhances access to justice for taxpayers, and embodies fair and clear procedural rules which are instrumental to realize procedural justice for taxpayers. A tax system should thus strive to create a fair tax dispute resolution system although the overall design of the system may vary among jurisdictions. Despite such variation, the practice of many countries shows

\footnotetext{
${ }^{190}$ Civil Procedure Code, cited above at note 92, see Arts. 394-455.

${ }^{191}$ Interview with Mulugeta Ayalew, cited above at note 30.

${ }^{192}$ Interviewees included in this piece informed the author.
} 
Tax Appeal Proceedings before the Federal Tax Appeal Commission in Ethiopia... 237

that tax decisions of the tax authority are reviewed by a tax appeal tribunal which is outside the regular judiciary and whose decisions are final and conclusive where the dispute involves only questions of fact. Aggrieved taxpayers take their appeal to the regular courts where the decision made by the tax appeal tribunal contains an error of law.

In Ethiopia, too, the appeal to a tax appeal commission has remained one of the most important features of the Ethiopian tax dispute resolution system starting from the early 1940s in spite of change of regimes and differences in ideological orientation. Under the current FTAP, a taxpayer who is dissatisfied by a decision of the Tax Authority and who wants to challenge the decision is entitled to take his appeal to the FTAC. Comparing the provisions of this proclamation with the provisions of the previous proclamations shows that some improvements, which are meant to enhance access to justice of the taxpayers and ensure procedural fairness of the system, have been made. However, there are still gaps and problems (discussed in the preceding sections of this article) that need to be addressed.

There are critical problems regarding appellate proceedings at the FTAC. First, there are uncertainties and ambiguities surrounding the scope of review power of the FTAP which should be clearly defined. Secondly, the power of the Prime Minister with regard to determining the number and composition of members of the FTAC has to be reconsidered by the lawmaker since this issue must not be left to absolute discretion of the executive organ. In this connection, the lawmaker has to provide (in future revision of the Proclamation) that the business community should be represented in the FTAC since such was the trend in Ethiopia starting from the Imperial Regime until the coming into force of the FTAP in 2016.

Third, although there is an improvement with regard to the advance tax deposit requirement as a precondition for lodging an appeal to the FTAC, it has to be further improved with regard to percentage and mode of discharging such stringent duty. In this regard, the 50\% deposit requirement needs to be reduced to thresholds such as $30 \%$ and $40 \%{ }^{193}$ based on thorough economic and legal analysis concerning the impact of such reduction on the revenue needs of the Government and the right of access to justice for taxpayers. Under exceptional circumstances, the legal reform in

193 Nearly all the interviewees have suggested this reasonable range which strikes a balance between the interest of the government and the taxpayers. Most taxpayers who participated in the public consultations on the draft PTAP suggested that the $50 \%$ deposit requirement should be reduced as low as $25 \%$ in order to realize taxpayers' right of access to justice. 
this regard is also expected to allow securities for the advance tax deposit through real securities such as mortgage, pledge and financial guarantee bond so as to strike a balance between the right to access to justice of taxpayers and the need to collect tax revenues as early as possible. Moreover, a taxpayer who does not have any means whatsoever and who cannot produce any real security should be allowed to lodge an appeal to the FTAC without meeting this precondition in view of such person's right to access to justice.

Fourth, there is a need to clearly stipulate that taxpayers have the right to an open hearing which is a fundamental human right of taxpayers enshrined under international human right instruments to which Ethiopia is a party. Fifth, the burden of proof imposed on taxpayers under all circumstances has to be seriously revisited. To this end, the law needs to stipulate exceptional circumstances where the tax authority bears the burden of proving a fact which is beyond the knowledge and reach of the taxpayer. In the absence of such balanced burden of proof, the tax dispute resolution system becomes unfair to the taxpayers and becomes susceptible to arbitrary exercise of power by the officials of the Tax Authority.

Sixth, the FTAC is unduly silent regarding the resolution of tax disputes that arise between the tax authority and the taxpayer at the time of execution of a decision. This leaves aggrieved taxpayers under the mercy of the Tax Authority. The gap in the FTAP in this regard needs to be addressed by amending the Proclamation because disputes between the taxpayer and Tax Authority inevitably arise at the stage of executing FTAC's decisions as well. 